\title{
Motivation, Economic Outcomes and Inspiration of "Financialization" in Non-financial Listed Companies
}

\author{
Xing-Yue WANG \\ 2013 Master of Accounting, Business School of Sichuan University, No.29 of Wang Jiang Road, \\ Chengdu, Sichuan, China \\ wxy1991623@163.com
}

Keywords: Financialization, Real sector, Financial sector, Non-financial listed companies, Economic outcomes, Risk prevention.

\begin{abstract}
Financialization is a process whereby financial markets, financial institutions, and financial elites gain greater influence over economic policy and economic outcomes. Financialization transforms the functioning of economic systems at both the macro and micro levels. Financialization operates through changes in the structure and operation of financial markets, changes in the behavior of non-financial corporations, and changes in economic policy. The principal impacts of this article are to: (1) elevate the significance of the financial sector relative to the real sector, (2) excavate the motivation, economic outcomes and inspiration of financialization in non-financial listed companies, (3) evaluate the risk of financialization and ways to prevent.
\end{abstract}

\section{Definition of Financialization}

Financialization was fist proposed by a group of foreign economics. It was the summary of the capitalist development stage since the 1980s, when developed countries regarded finance as economic core and used which to dominant the real economy. There is no uniform definition of financialization. Scholars now generally accept definition to Gerald Epstein. Financialization refers to the increasing importance of financial markets, financial motives, financial institutions, and financial elites in the operation of the economy and its governing institutions, both at the national and international level (Epstein 2001, p.1).

\section{Causes to financialization}

Financialization was spawned in the subprime mortgage crisis and economic recession. Its process began in the late seventies, developed in eighties, and intensified in the nineties. Just like a meteoric rise.

Since the recession from 1974 to 1975 , the development process of contemporary capitalism presented three major trends: (1) Global economic growth was slowing down; (2) Transnational monopoly (or oligopoly) companies ware expanded; (3) Financialization phenomenon was produced in capital accumulation.

In terms of monopoly, when the economy slowed down, when it came the recession, and when there was a small amount of monopolies, investors must seek investment outlets for pre-accumulated surpluses to obtain greater accumulation. But the similar industries, which produced these surpluses, would limit the space of profitable investment. The main countermeasure they took was to expand the demand of financial products, making them as one way to hold or increase the value of monetary capital. Profit-driven nature of capital resulted in a dual process of actual investment slowing down and financialization rising up.

From the perspective of global value chain, financial activities in non-financial companies can be divided into source of profits and use of profits. From the former point of view, multinational companies can reduce costs of imports and accumulate profits with advantages of global value chain. They can outsource parts of their business to make the progress of capital accumulation higher than the production rate of investment. From the latter point of view, when profits and accumulated cash flow are sufficient, more capital can be used for more financial activities, such as 
dividends distributing, stock repurchasing, options incentive, acquisitions and so on. Therefore, the formation of global value chain further promoted the process of enterprise "financialization".

\section{"Financialization" in non-financial listed companies-the combination of real industry and financial industry}

\section{The content and features of "financialization" in non-financial listed companies}

"Financialization" in non-financial listed companies expresses as a combination of real industrial and finance. It is an institutional arrangement of integration of real industrial economy and financial economy. As carriers of real industrial capital and financial capital, corporate entities and financial institutions are blended with common growth in economic movement. They develop through equity participation and personnel combination, and in basis of interest sharing and risk sharing. Its main characteristics are that corporate entities usually get involved in a variety of financial institutions, banks, insurance, trust and securities by investment, equity participation, mergers, acquisitions and other means.

\section{Motives and risks of "financialization" in non-financial listed companies}

Currently, the main motivations for companies entering into financial sector when developing real industry are as follows:

First, in the period of economic transition and institutional reform, enterprise use rent-seeking opportunities to obtain financial gain above the ordinary course of business profits due to profit motivation. In this case, enterprise can easily be carried away by the low cost of the high returns, even blindly speculate at the departure from operating principles in industrial entities.

Second, due to lack of cash flows and other reasons, entities in operating have to use finance to meet financing needs. But in today's financial markets, companies poor in management or lack in funds are often difficult to obtain bank loans. Thus greatly increase risks in guarantee and credit industry. There appear more fake guarantees and false accounting information in order to get bank loans. And also, improper operations lead to shares plunging in listed companies.

Third, when enterprises develop stable, they may make full use of accumulated earnings to keep and increase company value, and improve efficiency of internal funds. Such enterprises are usually in good condition of main business and cash flows are relatively abundant. So the risk is relatively small.

Furth, when entities develop to a certain size, they may adjust strategies of industry. Entities may be deeply involved in financial sectors, hold shares in financial companies and share profits of financial industry. Such as "combination and integration of real industry and financial industry" and "use financial leverage to deduct". The size of risks in such companies mainly depends on the reasonability of financial risk assessment, the stringency on controlling of capital chain, and whether the combination of capital structure and industrial structure match each other, etc.

\section{Development Status of "financialization" in non-financial listed companies}

\section{Situation in developed countries - the United States, for example}

"Financialization" in non-financial listed companies presents diversity in today's developed countries. But scholars generally agree that it is fastest growing in US.

Western scholars have found that currently in non-financial sector, the proportion of security incomes to cash inflows or corporate profits are increasing. What is more, incomes form securities are even higher than incomes from main business incomes. These all show that, profits of corporate entities are more and more inclined to the financial markets. Actual production and trade enthusiasm are declining. Accumulation rate is also dropping. Economy presents characteristics of chronic depression and instability.

Deepening financial trends in developed countries, as the representative of the United States, make the financial industry become a major source of one country's economic growth. Although 
the real economy and the financial industry show penetration and mutual interdependence, and get huge numbers of profit, it also leads many countries suffering from financial crisis and large areas of loss. The real economy, dragged down by the financial industry is facing a heavy blow.

\section{Situation in developing countries - China, for example}

In the case of China in nineties, real industry entities and financial sector entities were artificially isolated for a long time, resulting in the financial industry was very professional, and real industry was seriously lack of corporate finance experience. Over the past decade, the openness of capital markets in China has been growing day by day. And the domestic financial reform process has continued to accelerate. Industry experts believe that China's economy has an obvious trend of industrial financialization.

From the perspective of listed companies, non-financial listed companies invest their capital in the financial sector one after another in current. Investment income becomes an important part of financial statements. Some large state-owned enterprise groups directly get into the financial sector through establishing financial companies. Then the rate of return is closely solidary with the financial industry. At the same time, the potential risks are thus enhanced.

In short, the correlation of real industry and financial industry in China's non-financial listed companies is keeping rising. But compared to the United States, China's real sectors do not appear to have similar financial phenomenon like that in the US, which is significant and sustained. Capital accumulations in China are still more used for fixed asset investment and expanded reproduction. Although corporate financial profit is growing, it is more like an investment alternative in economic downturn.

\section{Economic consequences of "financialization" in non-financial listed companies}

\section{Positive effects of corporate financialization}

"Financialization" or "partially financialization" in non-financial listed companies provides a new form of wealth accumulation in enterprises. Operating under the combination mode allows entities to obtain a richer funding to create the conditions for expanded reproduction. It can help business grow and scale up, enhance competitiveness and influence.

Moreover, economic development under financialization makes credit and production factors timely and fully utilized. It promotes enterprises to improve their credit rating for the purpose to obtain funds. Above all, it is conducive to the healthy development of the economic market as a whole.

Finally, due to the real industrial capital get into financial institutions, capital in financial institutions increases, and then ability to resist risks in financial sectors strengthens.

In this sense, corporate financialization provides an important prerequisite foundation to the development of society and economy. It is also the special force to promote economic development.

\section{Crisis of corporate financialization}

The water that bears the boat is the same that swallows it up. Without proper control, financialization will bring risks to companies. Especially when corporate financialization becomes a trend, non-selective "follow suit" will endanger the survival of enterprises. When business conditions are not met of their own, companies must make choices carefully. Blind combination and investing limited funds to different sectors may make the core business seriously damaged and make companies fall into the trap of funding fracture.

If enterprises consider financing as final motives, they may regard financial institutions or financial instruments as means of financing. To achieve their goals, they may cheat, or even violate the law of financial operations. In this case, not only corporate reputation will be damaged, the event will also become a negative example in the market. Without proper control or lack of supervision, it may lead to other companies' following regardless of the consequences, and disturbing the market order. 
When entities are in the process of financialization, if the profit-motive is obvious, they could do anything at the expense of businesses or financial institutions. Finally the consequences are enterprises virtualized and financial institutions hollowed.

Being superstructure of modern economy, financial economy is still instable in current times. It is relatively independent and easily digressive with the real economy, which is the base of modern economy. It will lead to a lot of economic problems, even the outbreak of the financial crisis and the economic crisis.

Some developing countries are rush to open up financial markets. But then they are perilously raging in waves in the international financial markets and frequently burst into financial crisis and economic crisis, which seriously damage the economic organism and hinder the economic development.

\section{Enlightenment and risk prevention of corporate financialization in China}

Currently our country has already allowed some financial institutions invest in real industrial entities. But there are still strict eligible requirements for investors' qualifications and investment directions. Many obstacles still exist in the penetration of financial capital to real industries. To solve the problems, our country needs to regulate and supervise financialization in the level of enterprise and nation.

\section{The enterprise level}

From the enterprise level, if companies choose financialization, they should note the followings:

One is to be familiar with the operations of the financial rules, the difference between characteristics of risk and return in different enterprises, and the characteristics and operating requirements of various financial instruments to make the correct choice in financial scheme.

The second is to ensure reasonable combination of product management and capital management, and of industrial capital and financial capital. So that the financial economy and industrial economy will be continuously integrated, and promote each other with common development, preventing the negative impacts brought by excessive financialization.

The third is that when industrial companies deeply involved in financial sectors, they should remain their relative independent, and so to the financial institutions. It may prevent vicious incidents such as entities using controlling stake in the financial institution to hollow financial institutions.

\section{The national regulation level}

There are still problems in process of financialization in China. Such as the level of development is limited and risk control level is not high enough. In this way, not only does not financialization play a significant role in improving economic efficiency, but also causes weakness of the system. The real economy will be more vulnerable to the impact of the financial crisis. Thus, strengthen financial supervision is a priority in the current when financialization is becoming the development trend of China's economy.

China should strengthen the system as follows:

First, further improve the market financing system, providing convenient and safe access for corporate finance.

Second, strengthen and improve the system construction of financial institutions market admittance to raise the threshold of business entities involving in the investment banking industry. Prevent the risk of corporate finance.

Third, establish system for financial institutions to disclosure information externally. Play the market as a role of supervision on financial institutions.

Fourth, because that corporate finance involves different departments, different industries and different professions, strengthen mechanism of disposal and coordination among the various industry sectors is necessary. Also prevent fragmentation and strengthen the integrity and soundness of the work are important. 
Finally, establish a sound market with risk warning system and response mechanisms. Improve the market exit system. Enable financial enterprises in a reasonable competition environment and operate on a "what goes in, must come out" principle. Then ensure sustainable and healthy development of the financial ecology.

\section{Summary}

In summary, financialization is the inevitable trend for rapid economic development and it is of importance for commercial enterprises to seek new profit point. The financial industry has its unique value creation point, and it is an integral part of the modern economy.

While non-financial listed companies in a rapid process of financialization, we should also give a clear understanding of this combination:

The risks of the financial industry cannot be ignored. The real economy and the financial economy need a total of promoting coordination. Quality and control level of related professionals need to be further improved. Only in these ways can improve the real industry and financial ecology, then ensure sustainable and stable of economy.

\section{References}

[1] B. F. John, Y. N. Wang, and J. L. Chen, Financialization of capitalism, J. Foreign Theoretical Trends. 2007-07.

[2] G. Epstein, Financialization, Rentier Interests, and Central Bank Policy, Manuscript, Department of Economics, University of Massachusetts, Amherst, MA, December. 2001.

[3] M Lavoie, Financialization Issues in a Post Keynesian Stock-flow Consistent Model, J. Finance-led Capitalism, Berlin, Germany, 2007.

[4] P. Arestis, A. D. Luintel, and K. B. Lutinel, Financial structure and economic growth, CEPP working paper, 2005.

[5] P. Skott and S. Ryoo, Macroeconomic Implications of Financialization, Working Paper, Department of Economics, University of Massachusetts, Amherst, MA. 2007-08. 